Reviu Akuntansi dan Bisnis Indonesia, Vol. 5 No. 2, Hlm 197-207, Desember 2021

Website: http://journal.umy.ac.id/index.php/rab

\title{
Pengaruh Motivasi Kerja, Self Efficacy dan Internal Locus of Control Terhadap Kinerja Karyawan Badan Kredit Desa (BKD)
}

Citra Dhistia Murti; Evy Rahman Utami

Program Studi Akuntansi Universitas Muhammadiyah Yogyakarta

I N F O A R T I K E L

Kata Kunci:

Work Motivation; Self

Efficacy; Internal Locus of

Control; Employee

Performance; Badan Kredit

Desa (BKD)

Jenis Artikel:

Penelitian Empiris

Korespondensi:

citradhist@gmail.com

\section{Proses Artikel:}

Diterima 5 November 2021

Review 12 Desember 2021

Revisi 28 Desember 2021

Revisi 30 Desember 2021

Diterbitkan Desember 2021

\section{Sitasi:}

Murti, C.D., \& Utami, E.R.

(2021). Pengaruh Motivasi

Kerja, Self Efficacy dan Internal

Locus of Control Terhadap

Kinerja Karyawan Badan Kredit

Desa (BKD). Reviu Akuntansi

dan Bisnis Indonesia, 5(2), 197 -

207.

Link Artikel:

10.18196/rabin.v5i2.13550

\section{A B S TRAK}

\section{Latar Belakang:}

Penelitian ini dilatarbelakangi oleh data yang menunjukkan adanya persaingan antara Badan Kredit Desa (BKD) dengan bank umum lainnya yang dapat mempengaruhi kinerja karyawan, sehingga peneliti tertarik untuk melakukan penelitian ini.

\section{Tujuan:}

Penelitian ini bertujuan untuk menguji pengaruh motivasi kerja, self efficacy, dan internal locus of control terhadap kinerja karyawan BKD.

\section{Metode Penelitian:}

Penelitian ini menggunakan metode survey dengan menyebar 132 kuesioner kepada karyawan BKD. Teknik pengambilan sampel menggunakan metode purposive sampling. Teknik analisis data menggunakan regresi linear berganda dengan aplikasi SPSS versi 2.0.

\section{Hasil Penelitian:}

Hasil penelitian menunjukkan bahwa motivasi kerja berpengaruh positif terhadap kinerja karyawan, self efficacy dan internal locus of control tidak berpengaruh terhadap kinerja karyawan.

\section{Keterbatasan Penelitian:}

Penelitian ini hanya menggunakan data kuesioner, tanpa menggunakan wawancara sehingga hasil yang diperoleh kurang optimal.

\section{Keaslian/Novetly Penelitian:}

Penelitian ini menambah variabel independen motivasi kerja dan menggunakan objek penelitian yaitu Badan Kredit Desa. Variabel motivasi kerja ditambah karena hasil motivasi kerja sebelumnya belum konsisten.

(C) 2021 RAB. Published by Universitas Muhammadiyah Yogyakarta

\section{PENDAHULUAN}

Persaingan antara Badan Kredit Desa (BKD) dengan bank umum lainnya merupakan tantangan yang harus dihadapi oleh BKD pada saat ini (BKDOnline, 2017). Persaingan antara BKD dengan bank umum terjadi karena bank umum juga memberikan kredit atau pembiayaan dalam pengembangan usaha mikro, kecil, dan menengah. Adanya persaingan tersebut mengharuskan BKD untuk memperhatikan nasabah dengan memberikan pelayanan terbaik. Kinerja BKD yang baik diharapkan dapat menjadikan nasabah puas atas pelayanan yang diberikan. 
BKD perlu dikelola dengan baik, amanah, dan jujur. Karyawan BKD harus memiliki kejujuran, konsisten dan ketekunan agar BKD dapat dimanfaatkan dengan maksimal (Umar, 2017). Oleh karena itu, pengukuran kinerja dibutuhkan untuk kemajuan BKD. Pengukuran kinerja dalam BKD dilakukan untuk mengetahui apakah hasil yang dicapai telah sesuai dengan perencanaan. Kinerja karyawan yang meningkat berarti BKD tersebut dapat mencapai tujuan dari didirikannya BKD tersebut. Pegawai BKD perlu memberikan informasi mengenai kinerja kepada nasabah guna membangun kepercayaan.

Kinerja mengarah pada suatu tingkat pencapaian tugas yang dilakukan oleh seseorang (Susetyo dkk., 2016). Karyawan yang telah melaksanakan tugas- tugasnya dengan baik dan benar maka akan meningkatkan kinerja organisasi (Murty \& Hudiwinarsih, 2012). Terdapat tiga faktor yang mempengaruhi kinerja karyawan, yaitu faktor eksternal lingkungan organisasi, faktor internal lingkungan organisasi dan faktor internal karyawan (Ary \& Sriathi, 2019). Faktor internal karyawan diasumsikan sebagai faktor -faktor yang berasal dari dalam diri yang merupakan bawaan dari lahir maupun ketika berkembang (Hendrico \& Achnes, 2014). Faktor bawaan seperti bakat, kepribadiaan, serta keadaan jiwa maupun fisik, sedangkan faktor yang muncul ketika berkembang seperti ketrampilan, semangat kerja dan motivasi kerja.

Motivasi kerja merupakan salah satu cara untuk meningkatkan kualitas kinerja yang berasal dari faktor internal karyawan. Karyawan akan merasa termotivasi ketika menerima hasil dari pekerjaannya (Sumampouw, 2013). Organisasi perlu memperhatikan faktor yang dapat mempengaruhi kinerja karyawan, peran organisasi dalam meningkatkan motivasi kerja dapat mendorong terciptanya sikap professional sehingga kinerja dapat meningkat (Sembiring, 2020). Hasil penelitian (Wisana \& Wirajaya, 2015) dan (Purwanti \& Rasmini, 2015) membuktikan bahwa motivasi kerja berpengaruh positif terhadap kinerja karyawan. Disisi lain, penelitian (Oktaviani \& Marlinah, 2014) menunjukkan bahwa tidak ada pengaruh motivasi kerja terhadap kinerja.

Self-efficacy dinyatakan sebagai kepercayaan seseorang bahwa dia dapat menjalankan sebuah tugas pada sebuah tingkat tertentu, adalah salah satu dari faktor yang memengaruhi aktivitas pribadi terhadap pencapaian tugas (Suprapta \& Setiawan, 2017). Hasil penelitian (Sebayang \& Sembiring, 2017), (Suprapta \& Setiawan, 2017), dan (Ary \& Sriathi, 2019) membuktikan bahwa hasil penelitian self efficacy berpengaruh positif terhadap kinerja karyawan. Self efficacy dari diri karyawan akan membuat seseorang bekerja lebih giat agar kinerja meningkat (Sebayang \& Sembiring, 2017). Hasil penelitian (Kaseger, 2013) dan (Prasetya dkk., 2013) menunjukkan bahwa tidak ada pengaruh antara self efficacy terhadap kinerja karyawan.

Internal locus of control merupakan kepercayaan dari dalam diri untuk mengendalikan peristiwa dan menerima konsekuensi yang memengaruhi kehidupan individu (Setyowati, 2017). Hasil penelitian (Oktaviani \& Marlinah, 2014) dan (Ary \& Sriathi, 2019) membuktikan bahwa internal locus of control berpengaruh positif terhadap kinerja karyawan. Seseorang yang memiliki internal locus of control akan dengan mudah melakukan tugas-tugasnya sehingga akan meningkatkan kinerja (Jationo \& Rachbini, 2015). Namun, hasil penelitian (Nur, 2014) dan (Artiningsih \& Rasyid, 2013) menunjukkan bahwa intenal locus of control tidak berpengaruh terhadap kinerja karyawan. Internal locus of control tidak berpengaruh terhadap kinerja karyawan disebabkan karena ketidakpuasan karyawan sehingga adanya keinginan untuk mencari pekerjaan lain.

Penelitian ini merupakan replikasi dari penelitian yang dilakukan oleh (Ary \& Sriathi, 2019). Adapun perbedaan penelitian ini dengan penelitian sebelumnya yaitu penelitian ini dengan menambah variabel motivasi kerja dan menggunakan objek penelitian yaitu BKD. BKD merupakan perusahaan milik desa yang beroperasi di desa yang diurus sebagai perusahaan tersendiri dan terpisah dari kekayaan lain milik desa yang bersangkutan. Variabel motivasi kerja ditambahkan karena motivasi kerja merupakan faktor intrisik karyawan yang berpengaruh terhadap kinerja karyawan. Tujuan penelitian ini untuk mengetahui pengaruh motivasi kerja, self efficacy, dan internal locus of control terhadap kinerja karyawan BKD Kabupaten Batang.

Penelitian ini memiliki kontribusi bagi ilmu pengetahuan dan bagi BKD Kabupaten Batang. Bagi ilmu pengetahuan, penelitian ini berkontribusi sebagai bahan untuk memperluas ilmu pengetahuan terkait dengan pengaruh motivasi kerja, self efficacy, dan internal locus of control 
terhadap kinerja karyawan. Sedangkan bagi BKD Kabupaten Batang, penelitian ini berkontribusi sebagai bahan evaluasi kepada pimpinan BKD untuk lebih memperhatian dan membangun kepercayaan dari karyawan BKD.

\section{TINJAUAN LITERATUR DAN PERUMUSAN HIPOTESIS}

Teori yang digunakan dalam penelitian ini adalah teori motivasi dan atribusi. Teori motivasi yang dikemukakan oleh (Maslow, 1943) menyatakan bahwa perilaku manusia dipengaruhi oleh adanya motivasi dengan tujuan untuk mengarahkan perilaku manusia agar bisa diarahkan untuk mencapai tujuan. Sedangkan teori atribusi (Heider, 1958) merupakan teori yang menyatakan bahwa perilaku seseorang ditentukan oleh faktor internal dan eksternal. Teori ini mengacu pada bagaimana seseorang menjelaskan penyebab perilaku orang lain atau dirinya yang ditentukan oleh sikap, karakter, sifat, keadaan dari luar dan lain sebagainya. Adanya teori atribusi dan motivasi berhubungan dengan kinerja karyawan yaitu dengan termotivasinya karyawan dalam mengerjakan pekerjaan, maka kinerja karyawan tersebut akan meningkat.

\section{Pengaruh Motivasi Kerja Terhadap Kinerja Karyawan}

Pemberian motivasi kepada karyawan akan membuat karyawan terpacu untuk bekerja sesuai dengan acuan kerja dan bertanggung jawab sehingga tujuan perusahaan akan tercapai (Murty \& Hudiwinarsih, 2012). Teori motivasi menyatakan bahwa seseorang akan merasa terdorong untuk memenuhi kebutuhan yang paling kuat sesuai dengan keadaan (Maslow, 1943). Konsep teori motivasi menjelaskan bahwa kebutuhan seseorang dapat disusun sesuai dengan kebutuhan terendah sampai tertinggi. Dengan adanya kebutuhan yang harus dipenuhi maka karyawan akan meningkatkan kinerjanya.

Motivasi merupakan faktor yang berkontribusi terhadap kinerja. Adanya motivasi yang dimiliki oleh karyawan membuat tujuan dari perusahaan dapat berjalan dengan maksimal dan memuaskan. Motivasi yang positif dapat mempengaruhi karyawan agar menjalankan sesuatu sesuai dengan tujuan dari perusahaan (Purwanti \& Rasmini, 2015). Karyawan yang memiliki motivasi yang tinggi, mereka akan berupaya untuk melakukan semaksimal mungkin tujuan yang ditetapkan oleh perusahaan (Murty \& Hudiwinarsih, 2012). Penelitian yang dilakukan oleh (Sembiring, 2020), (Purwanti \& Rasmini, 2015), dan (Murty \& Hudiwinarsih, 2012) menunjukkan adanya pengaruh positif antara motivasi kerja terhadap kinerja karyawan.

Motivasi merupakan faktor yang berkontribusi terhadap kinerja. Adanya motivasi yang dimiliki oleh karyawan membuat tujuan dari perusahaan dapat berjalan dengan maksimal dan memuaskan. Motivasi yang positif dapat mempengaruhi karyawan agar menjalankan sesuatu sesuai dengan tujuan dari perusahaan (Purwanti \& Rasmini, 2015). Karyawan yang memiliki motivasi yang tinggi, mereka akan berupaya untuk melakukan semaksimal mungkin tujuan yang ditetapkan oleh perusahaan (Murty \& Hudiwinarsih, 2012). Berdasarkan uraian diatas, maka rumusan hipotesis yang diajukan:

\section{$\boldsymbol{H}_{i}$ : Motivasi kerja berpengaruh positif terhadap kinerja karyawan.}

\section{Pengaruh Self Efficacy Terhadap Kinerja Karyawan}

Self Efficacy merupakan kepercayaan seseorang atas kemampuannya dalam menguasai situasi dan menghasilkan sesuatu yang menguntungkan (Santrock, 2007). Self efficacy dapat mendorong karyawan untuk menjelaskan tentang kegagalan ataupun keberhasilan yang dialami. Self efficacy juga dapat berpengaruh bagi individu dalam bertindak dan membuat keputusan untuk mencapai tujuannya (Ary \& Sriathi, 2019). Teori atribusi menyatakan bahwa perilaku seseorang berasal dari dalam diri seseorang (Heider, 1958). Perilaku yang berasal dari dalam diri merupakan perilaku yang diyakini berada di bawah kendali pribadi seseorang. Seseorang yang memiliki kepercayaan diri dan keyakinan terhadap keberhasilan yang dicapai membuat seseorang menjadi giat dalam bekerja 
untuk mencapai hasil terbaik. Oleh karena itu, self efficacy yang tinggi dapat memberikan motivasi karyawan untuk meningkatkan kinerja (Sebayang \& Sembiring, 2017).

Self efficacy merupakan faktor personal yang dapat menyebabkan perubahan perilaku dari individu. Adanya self efficacy yang tinggi akan membuat karyawan lebih optimis dalam menyelesaikan pekerjaannya. Kinerja karyawan akan meningkat seiring dengan meningkatnya self efficacy. Penelitian yang dilakukan oleh (Sebayang \& Sembiring, 2017), (Suprapta \& Setiawan, 2017), dan (Ary \& Sriathi, 2019) menunjukkan adanya pengaruh self efficacy terhadap kinerja karyawan.

Self efficacy merupakan faktor personal yang dapat menyebabkan perubahan perilaku dari individu. Adanya self efficacy yang tinggi akan membuat karyawan lebih optimis dalam menyelesaikan pekerjaannya. Kinerja karyawan akan meningkat seiring dengan meningkatnya self efficacy. Berdasarkan uraian diatas, maka rumusan hipotesis yang dapat diajukan:

\section{$\boldsymbol{H}_{2}$ : Self Efficacy berpengaruh positif terhadap kinerja karyawan.}

\section{Pengaruh Internal Locus of Control Terhadap Kinerja Karyawan}

Internal locus of control merupakan karakteristik psikologis sebagai keyakinan masing-masing individu karyawan tentang kemampuannya untuk bisa mempengaruhi semua kejadian yang berkaitan dengan dirinya dan pekerjaannya (Pranata \& Putri, 2017). Teori atribusi menjelaskan perilaku yang berhubungan dengan sikap dan karakteristik individu sehingga individu tersebut dapat menghadapi situasi tertentu (Heider, 1958). Dengan adanya karyawan yang cenderung memiliki internal locus of control yang dipercaya dapat memecahkan masalah yang dihadapi dan menciptakan kepuasan pekerjaan sehingga dapat meningkatkan kinerja organisasi (Sudiartini \& Mimba, 2018).

Salah satu faktor yang mempengaruhi kinerja yaitu tipe personal individu yang mana individu dengan internal locus of control akan lebih berorientasi pada tugas yang dikerjakan sehingga akan meningkatkan kinerja (Wiriani dkk., 2013). Individu yang mempunyai internal locus of control menunjukkan sikap kompetitif, suka bekerja keras, dan ingin selalu berusaha lebih baik sehingga mengarah pada pencapaian kinerja yang lebih baik. Penelitian yang dilakukan oleh (Sudiartini \& Mimba, 2018), (Setyowati, 2017), dan (Ary \& Sriathi, 2019) menunjukkan adanya pengaruh internal locus of control terhadap kinerja karyawan.

Salah satu faktor yang mempengaruhi kinerja yaitu tipe personal individu yang mana individu dengan internal locus of control akan lebih berorientasi pada tugas yang dikerjakan sehingga akan meningkatkan kinerja (Wiriani dkk., 2013). Individu yang mempunyai internal locus of control menunjukkan sikap kompetitif, suka bekerja keras, dan ingin selalu berusaha lebih baik sehingga mengarah pada pencapaian kinerja yang lebih baik. Berdasarkan uraian diatas, maka rumusan hipotesis yang dapat diajukan:

\section{$\boldsymbol{H}_{3}$ : Internal locus of control berpengaruh positif terhadap kinerja karyawan.}

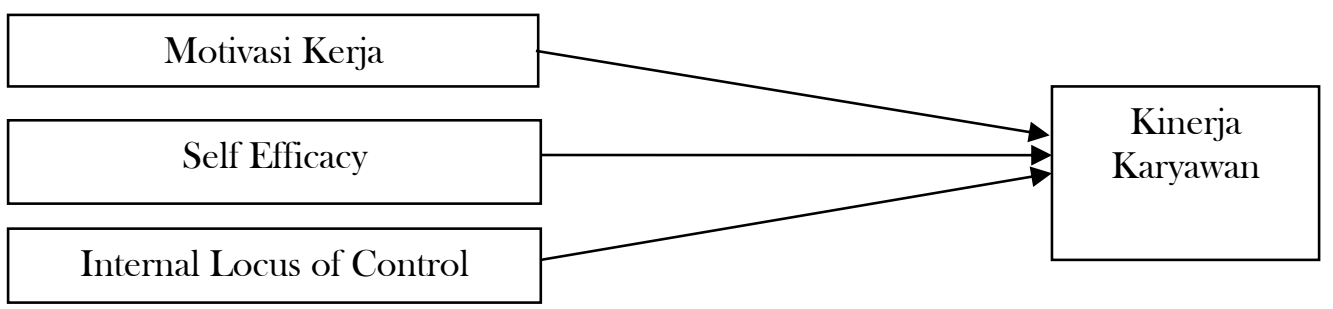

Gambar 1 Model Penelitian 


\section{METODE PENELITIAN}

Penelitian ini dilakukan dengan menggunakan pendekatan kuantitatif dengan data yang bersumber dari data primer. Penelitian ini dilaksanakan di 42 unit Badan Kredit Desa Kabupaten Batang dengan 132 responden. Dalam pengambilan sampel, penelitian ini menggunakan teknik purposive sampling, dengan kriteria (1) Kepala Badan Kredit Desa di setiap unit. (2) Karyawan Badan Kredit Desa yang menerima kompensasi.

Dalam penelitian ini yang menjadi variabel dependen adalah kinerja karyawan yang diukur dengan menggunakan kuesioner dengan skala likert 1-5 point. Penilaian kinerja karyawan mengikuti indikator yang digunakan penelitian (Suhardi, 2019).

Motivasi kerja dalam penelitian ini yaitu sesuatu yang menggerakkan diri karyawan yang terarah untuk mencapai suatu tujuan yaitu kesejahteraan Badan Kredit Desa. Ada 10 item pertanyaan yang dikembangkan oleh (Suhardi, 2019) yang dipakai mengukur motivasi kerja. Dengan menggunakan skala likert 5 poin, skor yang rendah menunjukkan motivasi kerja yang rendah dan skor tinggi menunjukkan motivasi kerja yang tinggi.

Self efficacy dalam penelitian ini yaitu merupakan keyakinan dari dalam diri seseorang mengenai sejauh mana orang tersebut mampu mengerjakan tugas mencapai tujuan dan merencanakan seseuatu untuk mencapai tujuan. Ada 5 item pertanyaan yang dikembangkan oleh (Jayanti, 2015) yang dipakai untuk mengukur self efficacy. Dengan menggunakan skala likert 5 poin, skor yang rendah menunjukkan self efficacy yang rendah dan skor tinggi menunjukkan self efficacy yang tinggi.

Internal locus of control dari karyawan dalam penelitian ini berhubungan dengan kinerja Badan Kredit Desa bila karyawannya memiliki pandangan tentang karirnya dalam bekerja. Ada 7 item pertanyaan yang dikembangkan oleh (Wiriani dkk., 2013) yang dipakai untuk mengukur internal locus of control. Dengan menggunakan skala likert 5 poin, skor yang rendah menunjukkan internal locus of control yang rendah dan skor tinggi menunjukkan internal locus of control yang tinggi.

Teknik analisis data yang digunakan dalam penelitian ini adalah analisis regresi berganda dengan tahapan statistik deskriptif, selanjutnya uji kualitas data, uji asumsi klasik, analisis regresi linear berganda, uji hipotesi melalui uji koefisien determinan dan uji signifikansi parsial.

\section{HASIL DAN PEMBAHASAN}

Lokasi penelitian dilaksanakan di Badan Kredit Desa Kabupaten Batang. Responden dalam penelitian ini adalah karyawan Badan Kredit Desa Kabupaten Batang. Berdasarkan Tabel 1 dapat diketahui bahwa terdapat 10 kuesioner yang tidak kembali, sehingga kuesioner yang digunakan dapat diolah adalah sebanyak 132 kuesioner. Ringkasan pengiriman sera pengembalian kuesioner disajikan dalam Tabel 1 .

Tabel 1 Ringkasan Pengiriman dan Pengembalian Kuesioner

\begin{tabular}{lcc}
\hline \multicolumn{1}{c}{ Data Klasifikasi } & Jumlah & Persentase \\
\hline Jumlah kuesioner yang disebar & 142 & 100 \\
Kuesioner yang kembali & 132 & 93 \\
Kuesioner yang tidak kembali & 10 & 7 \\
Total kuesioner yang dapat diolah & 132 & 93 \\
\hline
\end{tabular}


Ringkasan data statistik karakteristik responden disajikan dalam Tabel 2.

Tabel 2 Ringkasan Data Statistik Karakteristik Responden

\begin{tabular}{|c|c|c|c|}
\hline No. & Karakteristik & Total & Persentase \\
\hline \multirow[t]{5}{*}{1.} & Umur & & \\
\hline & $<30$ tahun & 23 & 17.4 \\
\hline & 30-45 tahun & 79 & 59.8 \\
\hline & $>45$ tahun & 30 & 22.7 \\
\hline & Total & 132 & 100 \\
\hline \multirow[t]{4}{*}{2.} & Jenis Kelamin & & \\
\hline & Laki- laki & 73 & 55.3 \\
\hline & Perempuan & 59 & 44.7 \\
\hline & Total & 132 & 100 \\
\hline \multirow[t]{5}{*}{3.} & Pendidikan Terakhir & & \\
\hline & SMP & 6 & 4.5 \\
\hline & SMK/SMA & 100 & 75.8 \\
\hline & Diplomat/ S1 & 26 & 19.7 \\
\hline & Total & 132 & 100 \\
\hline \multirow[t]{12}{*}{4.} & Jabatan & & \\
\hline & Direksi & 2 & 1.5 \\
\hline & Auditor Internal & 2 & 1.5 \\
\hline & AO NPL & 1 & 0.8 \\
\hline & Sekretaris & 2 & 1.5 \\
\hline & Kepala Cabang & 2 & 1.5 \\
\hline & Manager Unit & 2 & 1.5 \\
\hline & Admin Unit & 4 & 3.0 \\
\hline & Teller & 3 & 2.3 \\
\hline & Marketing Unit & 34 & 25.8 \\
\hline & Pengelola Unit & 80 & 60.6 \\
\hline & Total & 132 & 100 \\
\hline \multirow[t]{8}{*}{5.} & Lama Bekerja & & \\
\hline & 1-5 tahun & 58 & 43.9 \\
\hline & 6-10 tahun & 50 & 37.9 \\
\hline & 11-15 tahun & 9 & 6.8 \\
\hline & 16-20 tahun & 11 & 8.3 \\
\hline & 21-25 tahun & 2 & 1.5 \\
\hline & 26-30 tahun & 2 & 1.5 \\
\hline & Total & 132 & 100 \\
\hline \multirow[t]{5}{*}{6.} & Unit Kerja & & \\
\hline & Cabang Batang Timur & 29 & 22.0 \\
\hline & Cabang Batang Barat & 25 & 18.9 \\
\hline & Cabang Batang Kota & 78 & 59.1 \\
\hline & Total & 132 & 100 \\
\hline
\end{tabular}

Berdasarkan Tabel 2 dapat diketahui bahwa karakteristik responden dalam penelitian ini meliputi usia, jenis kelamin, pendidikan, jabatan, unit kerja, dan lama bekerja. Responden terbanyak dalam penelitian ini adalah laki-laki dengan pendidikan terakhir yang paling dominan SMA/SMK. Jabatan paling dominan dalam penelitian ini adalah pengelola unit yaitu sebanyak 80 responden. Responden rata-rata telah bekerja di BKD Kabupaten Batang selama 1-5 tahun. Responden paling dominan dalam penelitian ini bekerja di unit kerja Cabang Batang Kota. Hasil statistik deskriptif disajikan dalam Tabel 3. 
Tabel 3 Hasil Uji Statistik Deskriptif

\begin{tabular}{lccccccc}
\hline \multicolumn{1}{c}{ Variabel } & N & \multicolumn{2}{c}{ Teoritis } & & Aktual & Ket \\
& & Kisaran & Mean & Kisaran & Mean & $\begin{array}{c}\text { Std. } \\
\text { Deviasi }\end{array}$ & \\
\hline Kinerja Karyawan & 11 & $11-55$ & 33 & $33-55$ & 46.95 & 3.813 & Tinggi \\
Motivasi Kerja & 10 & $10-50$ & 30 & $32-48$ & 41.85 & 3.353 & Tinggi \\
Self Efficacy & 6 & $6-30$ & 18 & $18-30$ & 24.74 & 2.561 & Tinggi \\
$\begin{array}{l}\text { Internal Locus of } \\
\text { Control }\end{array}$ & 7 & $7-35$ & 21 & $21-35$ & 29.00 & 2.812 & Tinggi \\
\end{tabular}

Pada Tabel 3, menunjukkan bahwa nilai mean aktual seluruh variabel lebih tinggi daripada nilai mean teoritis. Artinya, karyawan BKD Kabupaten Batang menilai pengaruh variabel-variabel tersebut adalah tinggi.

Pada pernyataan mengenai variabel Motivasi Kerja, Self Efficacy, Internal Locus of Control dan Kinerja Karyawan, keseluruhan variabel lolos uji kualitas instrumen yaitu uji validitas dan reliabilitas serta lolos uji asumsi klasik yaitu uji normalitas, heteroskedastisitas, dan multikolinearitas. Analisis Regresi Linear Berganda diolah dengan bantuan software SPSS Statistik versi 22.0. dengan hasil yang dilihat pada Tabel 4 .

Tabel 4 Rangkuman Hasil Pengujian

\begin{tabular}{lcccc}
\hline \multicolumn{1}{c}{ Keterangan } & B & Std. Error & thitung & Sig \\
\hline Motivasi Kerja (X1) & 0,447 & 0,094 & 4,753 & 0,000 \\
Self Efficacy (X2) & 0,152 & 0,145 & 1,048 & 0,296 \\
Internal Locus of Control (X3) & 0,215 & 0,159 & 1,608 & 0,111 \\
Constant & 18,213 & 3,96 & & \\
R-Square & 0,293 & & & \\
Adjusted R-Square & 0,277 & & & \\
F-hitung & 17,703 & & & \\
Sig. F & 0 & & & \\
\hline
\end{tabular}

Pada Tabel 4, menunjukkan hasil regresi linear berganda, maka model persamaan regresi linear berganda dapat dirumuskan dengan:

$$
\mathrm{X}_{\mathrm{k \textrm {K }}}=18,213+0,447 \boldsymbol{X}_{M O^{+}}+0,152 X_{S E L F}+0,215 X_{\text {INTLOC }}+\mathrm{e}_{1}
$$

Pengujian model penelitian didasarkan pada hasil uji koefisien determinasi dan hasil uji $\mathbf{F}$. Berdasarkan hasil pengolahan data, nilai adjusted $\mathrm{R}$ square sebesar 0,277 artinya adanya hubungan antara variabel bebas motivasi kerja, self efficacy dan internal locus of control terhadap variabel terikat kinerja karyawan sebesar $27,7 \%$. Sisanya sebesar 72,3\% dijelaskan oleh variabel lain di luar penelitian ini. Dari Tabel rangkuman hasil pengujian di peroleh nilai Fhitung 17,703 > Ftabel 2,68 dengan p value sebesar 0,000. Berdasarkan hasil tersebut dapat disimpulkan bahwa model regresi yang diuji baik.

Dari Tabel 4, dapat disimpulkan bahwa $\mathbf{H}_{1}$ terdukung yang berarti bahwa motivasi kerja berpengaruh positif terhadap kinerja karyawan. Adanya motivasi kerja maka karyawan Badan Kredit Desa termotivasi dalam bekerja karena adanya suatu kebutuhan hidup yang harus dipenuhi. Tujuan dari mereka bekerja adalah untuk mendapatkan gaji serta tunjangan yang bisa digunakan untuk memenuhi kebutuhan hidup mereka. Motivasi kerja karyawan dipengaruhi oleh target pekerjaan, disiplin waktu, kreativitas, tanggung jawab pekerjaan, dan kerjasama yang telah ditentukan oleh Badan Kredit Desa. Karyawan Badan Kredit Desa yang dapat bekerja dengan baik dan memenuhi target akan mendapat insentif baik berupa finansial maupun non finansial dan memungkinkan untuk diberi promosi jabatan. Selain itu, Badan Kredit Desa juga memberikan perlindungan terhadap kerugian fisik kepada karyawan sehingga membuat karyawan merasa aman dan nyaman dalam melakukan pekerjaannya. Semakin tinggi motivasi kerja karyawan maka 
semakin tinggi kinerja karyawan dalam menyelesaikan pekerjaan dan begitu juga sebaliknya. Hal ini sejalan penelitian (Sembiring, 2020), (Purwanti \& Rasmini, 2015), dan (Suhardi, 2019). Penelitian (Sembiring, 2020) menyatakan bahwa motivasi berpengaruh positif terhadap kinerja karyawan pada Bank Sinarmas Medan. Selain itu, (Purwanti \& Rasmini, 2015) dalam penelitiannya menyatakan bahwa motivasi berpengaruh positif terhadap kinerja dewan komisaris BPR se-Kabupaten Gianyar. Penelitian yang dilakukan (Suhardi, 2019) juga menyatakan bahwa motivasi kerja berpengaruh positif terhadap kinerja karyawan PT. Asuransi Jiwa di Kota Batam.

Dari Tabel 4, dapat disimpulkan bahwa $\mathbf{H}_{2}$ tidak terdukung yang berarti bahwa self efficacy tidak berpengaruh terhadap kinerja karyawan. Hasil yang tidak signifikan ini kemungkinan dikarenakan karyawan merasa apa yang mereka kerjakan kurang memuaskan, sehingga mereka kurang yakin dalam melaksanakan pekerjaan dan tidak maksimal dalam mengerjakan tugasnya. Kepercayaan diri yang kurang juga dapat berpengaruh terhadap kinerja karyawan yang menjadi sering mengeluh setiap kali dimintai mengerjakan pekerjaan. Menurunnya kinerja dikarenakan karyawan tidak puas dengan apa yang mereka terima. Seperti masalah gaji, ketika karyawan sudah menyelesaikan pekerjaan mereka dengan baik atau bahkan sudah lewat target namun gaji yang mereka terima kurang sesuai dengan keinginan mereka. Hal ini membuat karyawan membandingkan apa yang mereka kerjakan dengan gaji yang mereka terima. Selain itu, rendahnya self efficacy disebabkan karena beban kerja yang kian meningkat yang menjadikan karyawan merasa terbebani dengan pekerjaan mereka. Hal tersebut juga bertolak belakang dengan teori atribusi bahwa dengan individu yang memiliki kepercayaan diri dan keyakinan terhadap keberhasilan akan membuat individu tersebut giat dalam bekerja untuk mencapai hasil terhasil. Hasil penelitian ini tidak sejalan dengan penelitian (Ary \& Sriathi, 2019) yang menyatakan bahwa self efficacy berpengaruh positif terhadap kinerja karyawan Ramayana Mal Bali. Namun penelitian ini sejalan dengan penelitian (Kaseger, 2013),(Prasetya dkk., 2013), dan (Noviawati, 2016). Penelitian yang dilakukan (Kaseger, 2013) menyatakan bahwa self efficacy tidak berpengaruh terhadap kinerja PT. Matahari Department Store Manado Town Square. (Prasetya dkk., 2013) dalam penelitian menyatakan bahwa self efficacy tidak berpengaruh terhadap kinerja dosen perguruan tinggi di wilayah se-eks Karesidenan Madiun. Penelitian (Noviawati, 2016) juga menyatakan bahwa self efficacy tidak berpengaruh kinerja karyawan pada divisi finance dan human resource PT. CocaCola Distribution Indonesia, Surabaya.

Dari Tabel 4, dapat disimpulkan bahwa $\mathrm{H}_{3}$ tidak terdukung yang berarti internal locus of control tidak berpengaruh terhadap kinerja karyawan. Hasil yang tidak signifikan ini kemungkinan dikarenakan rasa ketidakpuasan karyawan. Kondisi kerja yang kurang menyenangkan menyebabkan ketidakpuasan karyawan sehingga akan timbul keinginan untuk mencari pekerjaan lain. Karyawan merasa kurang mampu meyakinkan dirinya sendiri bahwa kesuksesan dan kegagalan yang didapat dalam hidup dipengaruhi oleh tindakan dan kemampuan dari individu masing masing. Selain itu, semakin rendah tingkat pendidikan seseorang maka semakin rendah pula tingkat kepercayaan diri dari seseorang (Anthony, 1992). Hal ini sesuai dengan data demografi responden yang mayoritas dari responden berpendidikan SMA. Semakin rendah tingkat pendidikan cenderung membuat seseorang bergantung kepada orang lain. Hal tersebut bertolak belakang dengan teori atribusi bahwa dengan individu yang memiliki internal locus of controldipercaya dapat memecahkan masalah yang terjadi dan menciptakan kepuasan pekerjaan sehingga meningkatkan kinerja (Sudiartini \& Mimba, 2018). Hasil penelitian ini sejalan dengan penelitian (Nur, 2014) dan (Artiningsih \& Rasyid, 2013). Penelitian yang dilakukan (Nur, 2014) menyatakan bahwa internal locus of control tidak berpengaruh terhadap kinerja karyawan bagian akuntansi dan keuangan pada Bank BPR di Tanjungpinang. (Artiningsih \& Rasyid, 2013) dalam penelitiannya menyatakan bahwa internal locus of control tidak berpengaruh terhadap kinerja karyawan RSUD Kotabaru.

\section{KETERBATASAN PENELITIAN}

Keterbatasan dari penelitian ini yaitu hanya menggunakan data kuesioner tanpa menggunakan wawancara sehingga hasil yang didapatkan kurang maksimal. Selain itu pemahaman dari responden 
terhadap pernyataan dalam kuesioner tergolong kurang serta sampel yang digunakan dalam penelitian ini terbatas jumlahnya. Penelitian selanjutnya diharapkan dapat menggunakan obyek penelitian yang lebih luas dan dapat menambah variabel yang masih jarang diteliti yang masih berkaitan dengan kinerja karyawan sehingga dapat menemukan perbedaan pada penelitian ini.

\section{KESIMPULAN}

Penelitian ini menguji dan menganalisis pengaruh motivasi kerja, self efficacy, dan internal locus of control terhadap kinerja karyawan BKD Kabupaten Batang. Hasil yang diperoleh dalam penelitian ini yaitu motivasi kerja berpengaruh positif terhadap kinerja karyawan, sedangkan self efficacy dan internal locus of control tidak berpengaruh terhadap kinerja karyawan.

Hasil penelitian ini dapat dijadikan sebagai bahan untuk memperluas ilmu pengetahuan mengenai konsep dan teori terkait dengan pengaruh motivasi kerja, self efficacy dan internal locus of control terhadap kinerja karyawan. Adanya penelitian ini juga dapat dijadikan sebagai bahan evaluasi pihak pimpinan BKD Kabupaten Batang untuk lebih memperhatikan dan membangun kepercayaan dari karyawan. Karyawan diharapkan mampu mempertahankan motivasi kerjanya dan lebih meningkatkan kepercayaan diri mereka.

\section{DAFTAR PUSTAKA}

Anthony, R. (1992). Rahasia Membangun Kepercayaan Diri (Terjemahan Rita Wiryadi). Jakarta: Binarupa Aksara.

Artiningsih, D., \& Rasyid, S. (2013). The Influence of Locus of Control, Organization Citizenship Behavior and Work's Life Quality to Employee's Performance. Jurnal Aplikasi Manajemen, 11(3), 365-373. Diakses dari https://jurnaljam.ub.ac.id/index.php/jam/article/view/582

Ary, I., \& Sriathi, A. (2019). Pengaruh Self Efficacy dan Locus of Control Terhadap Kinerja Karyawan (Studi Pada Ramayana Mal Bali). E-Jurnal Manajemen, 8(1), 30 - 53. https://doi.org/10.24843/EJMUNUD.2019.v08.i01.p02

BKDOnline. (2017). Empat Tantangan Kejahatan Perbankan di BPR. Diakses dari https://bkd.co.id/empat-tantangan-kejahatan-perbankan-di-bpr

Heider, F. (1958). The psychology of interpersonal relations. John Wiley \& Sons Inc.

Hendrico, M., \& Achnes, S. (2014). Faktor-Faktor yang Mempengaruhi Kinerja Pegawai di Dinas Kebudayaan dan Pariwisata Kota Pekanbaru. Jurnal Online Mahasiswa (JOM) Bidang Ilmu Sosial dan Ilmu Politik, 1(2), 1-10. Diakses dari https://jom.unri.ac.id/index.php/JOMFSIP/article/view/3260

Jationo, I., \& Rachbini, W. (2015). Good Governance, Komitmen Profesional dan Akuntabilitas Layanan Publik, Locus of Control Sebagai Intervening. Jurnal Riset Akuntansi \& Perpajakan (JRAP), 2(01), 78-88. Diakses dari https://doi.org/10.35838/jrap.v2i01.98

Jayanti, R. (2015). Pengaruh Skeptisme, Pengalaman Auditor dan Self Efficacy Terhadap Audit Judgement. Diakses dari http://weekly.cnbnews.com/news/article.html?no=124000

Kaseger, R. (2013). Pengembangan Karir dan Self-Efficacy Terhadap Kinerja Karyawan Pada Pt. Matahari Department Store Manado Town Square. Jurnal Riset Ekonomi, Manajemen, Bisnis dan Akuntansi, 1(4), 906-916. Diakses dari https://ejournal.unsrat.ac.id/index.php/emba/article/view/2827

Maslow, A. H. (1943). A theory of human motivation. Psychological Review, 50(4), 370-396. https://doi.org/10.1037/h0054346

Murty, W. A., \& Hudiwinarsih, G. (2012). Pengaruh Kompensasi, Motivasi Dan Komitmen Organisasional Terhadap Kinerja Karyawan Bagian Akuntansi (Studi Kasus Pada Perusahaan Manufaktur di Surabaya). The Indonesian Accounting Review, 2(02), 215. https://doi.org/10.14414/tiar.v2i02.97 
Noviawati, D. R. (2016). Pengaruh Self Efficacy terhadap Kinerja Karyawan dengan Motivasi sebagai Variabel Intervening (Studi pada Karyawan Divisi Finance dan Human Resources PT. Coca-Cola Distribution Indonesia, Surabaya). Jurnal Ilmu Manajemen (IIM), 4(3), 1-12. Diakses dari https://jurnalmahasiswa.unesa.ac.id/index.php/jim/article/view/17033

Nur, F. (2014). Pengaruh Locus of Control, Gaya Kepimpinan, Pemberian Kompensasi dan Motivasi Terhadap. Jurnal Universitas Maritim Raja Ali Haji, 16(4), 1-20.

Oktaviani, E., \& Marlinah, A. (2018). Pengaruh Tindakan Supervisi, Motivasi, Profesionalisme, Locus of Control, Konflik Peran Terhadap Kepuasan Kerja. Jurnal Bisnis Dan Akuntansi, 16(1), 61 - 74. Diakses dari https://jurnaltsm.id/index.php/JBA/article/view/98

Pranata, N., \& Putri, I. (2017). Internal Locus of Control Sebagai Pemoderasi Pengaruh Partisipasi Penganggaran Terhadap Senjangan Anggaran pada Bank Perkreditan Rakyat. E-Jurnal Akuntansi, $\quad$ 19(2), 855-884. Diakses dari https://ojs.unud.ac.id/index.php/Akuntansi/article/view/22277

Prasetya, V., Handayani, D., \& Purbandari, T. (2013). Peran Kepuasan Kerja, Self Esteem, Self Efficacy terhadap Kinerja Individual. Jurnal Riset Manajemen Dan Akuntansi Widya Mandala $\begin{array}{llll}\text { Madiun, } & \text { I(1), } & \text { 59-69. Diakses }\end{array}$ http://portal.widyamandala.ac.id/jurnal/index.php/jrma/article/view/90

Purwanti, N., \& Rasmini, N. (2015). Pengaruh Kompetensi, Motivasi, Komitmen Organisasi Pada Kinerja Dewan Komisaris BPR Sekabupaten Gianyar. E-Jurnal Akuntansi, 12(3), 686-704. Diakses dari https://ojs.unud.ac.id/index.php/Akuntansi/article/view/11723

Santrock, J. W. (2007). Psikologi Pendidikan Edisi Kedua. Jakarta: Kencana Prenada Media.

Sebayang, S., \& Sembiring, J. (2017). Pengaruh Self Esteem dan Self Efficacy Terhadap Kinerja Karyawan Studi Kasus di PT Finnet Indonesia. E-Proceeding of Management, 4(1), 335-345. Diakses dari https://openlibrarypublications.telkomuniversity.ac.id/index.php/management/article/view/43 $\underline{88}$

Sembiring, H. (2020). Pengaruh motivasi dan lingkungan kerja terhadap kinerja karyawan pada Bank Sinarmas Medan. Jurnal Akuntansi dan Manajemen, 13(1), 10-23. Diakses dari http://jurakunman.stiesuryanusantara.ac.id/index.php/jur1/article/view/13

Setyowati, S. (2017). Analisis Pengaruh Locus of Control Dan Stres Kerja Terhadap Kinerja Karyawa. Jurnal Ilmiah Manajemen \& Bisnis, 18(2), 129-139. http://dx.doi.org/10.30596\%2Fjimb.v18i2.1397

Sudiartini, N., \& Mimba, N.P.S.H. (2018). Pengaruh Locus of Control dan Budaya Organisasi berbasis Tri Hita Karana pada Kinerja Badan Pengawas. E-Jurnal Akuntansi, 22(1), 381-407. https://doi.org/10.24843/EJA.2018.v22.i01.p15

Suhardi, S. (2019). Pengaruh Motivasi Kerja, Kompetensi, Lingkungan Kerja dan Kompensasi Terhadap Kinerja Karyawan PT. Asuransi Jiwa di Kota Batam Dengan Organizational Citizenship Behavior Sebagai Variabel Intervening. Jurnal Benefita, 4(2), 296-315. Diakses dari http://ejournal.lldikti10.id/index.php/benefita/article/view/3670

Sumampouw, C. L. (2013). Pengaruh Kompensasi Terhadap Produktifitas Kerja Karyawan Pada PT. Bank Tabungan Pensiunan Nasional, Tbk Manado. Acta Diurna Komunikasi, 2(3), 122.

Diakses

dari

https://ejournal.unsrat.ac.id/index.php/actadiurnakomunikasi/article/view/2436

Suprapta, K., \& Setiawan, P. (2017). Pengaruh Beban Kerja, Kepuasan Kerja, Self Efficacy dan Time Budget Pressure Pada Kinerja Auditor. E-Jurnal Akuntansi, 19(1), 81-108. Diakses dari https://ojs.unud.ac.id/index.php/Akuntansi/article/view/24400

Susetyo, D.P., Sadeli, D., \& Surtikanti, S. (1970). Dukungan Manajemen Puncak, Kemampuan Teknik, Pelatihan Karyawan dan Kinerja Sistem Informasi Akuntansi Perbankan. Jurnal Riset Akuntansi \& Perpajakan (JRAP), 3(01), 109-120. https://doi.org/10.35838/jrap.2016.003.01.9

Umar, K. (2017). PT. BKD Batang Menerima Izin Usaha LKM. Diakses dari https://www.suaramerdeka.com/news/baca/18673/pt-bkd-batang-menerima-izin-usaha-lkm

Wiriani, W., Piatrini, P., Ardana, K., \& Juliarsa, G. (2013). Efek Moderasi Locus of Control pada Hubungan Pelatihan dan Kinerja Pada Bank Perkreditan Rakyat di Kabupaten Badung. Jurnal 
Ilmiah Akuntansi dan Bisnis, 8(2), 99-105. Diakses dari https://ojs.unud.ac.id/index.php/jiab/article/view/10864

Wisana, J. K. H., \& Wirajaya, I. G. A. (2015). Pengaruh Kompetensi, Motivasi, dan Komitmen Organisasi Pada Kinerja Manajerial Bank Perkreditan Rakyat Sekabupaten Gianyar. E-Jurnal Akuntansi Univeristas Udayana, 13(3), 828-856. Diakses dari https://ojs.unud.ac.id/index.php/Akuntansi/article/view/14075 